\title{
PENERAPAN ALTMAN Z-SCORE DALAM MEPREDIKSI KEBANGKRUTAN PADA PT BANK DANAMON INDONESIA Tbk
}

\author{
Eva Malina Simatupang \\ Politeknik Negeri Medan \\ evasimatupang14@gmail.com
}

\begin{abstract}
The tittle of research was "The Implementation of Altman Z-Score in Predicting Bankruptcy at PT Bank Danamon Indonesia Tbk. The purpose of this research was conducted to determine the risk of bankruptcy of PT Bank Danamon Tbk according to Altman Z-Score. The population in this research was the financial statement of PT Bank DanamonTbk and the samples in this research were reports of financial position (balance sheet) and income statement of PT Bank Danamon Tbk period 2018 - 2020. The type of data used is secondary data and the data collection techniques used were the documentation of the financial statements published through website https://www.danamon.co.id. The data analysis technique uses descriptive statistics and the Altman Z-Score Modification method. Based on the results of the data processing obtained Z-Score results at 2018 was 2,251; at 2019 was 2,4424; at 2020 was 2,0052. Based on the results of data analysis, it can be concluded that PT Bank Danamon Tbk is in the gray zone because the standard cut off value is $1.1<Z<2.6$. Bank Danamon is in a vulnerable condition (grey area) which means the company has the potential to experience financial difficulties but can still be overcome.
\end{abstract}

Keywords: Altman Z-Score, Prediction, Bankruptcy

\section{PENDAHULUAN}

Laba ( profit) perusahaan adalah indikator utama perusahaan untuk dapat mempertahankan kelangsungan hidup perusahaan. Semakin tinggi laba yang diperoleh suatu perusahaan diharapkan perusahaan lebih mampu untuk bertahan, bertumbuh, berkembang serta tangguh dalam menghadapi persaingan yang ada. Turunnya keuntungan yang diperoleh perusahaan secara terus menerus akan berdampak pada keberlanjutan usaha perusahaan. Oleh karena itu, perlu adanya kajian tentang analisis kinerja keuangan perusahaan dengan menggunakan Altman Z- Score.

Alat untuk menghindari kebangkrutan yang dapat digunakan untuk mendeteksi kebangkrutan. Beberapa alat pendeteksi kebangkrutan tersebut adalah Altman ZScore, Springate Model, dan Zmijewski Model. Model Altman Z-Score telah dikembangkan pada tahun 1968 oleh Edward Altman. Altman Z-Score merupakan model yang paling sering digunakan dalam melakukan penelitian prediksi kebangkrutan suatu perusahaan. Altman Z-Score memiliki tiga model penelitian yaitu model Altman Z-Score pertama (1968), model Altman Z-Score revisi (1983), dan model Altman Z-Score modifikasi (1995). (Rudianto, 2013: 254).

Penelitian ini menggunakan metode analisis Altman Z-Score karena mampu memberikan ketepatan prediksi sebesar 95\%. Analisis yang digunakan dalam model ini adalah empat rasio, yaitu modal kerja terhadap total aset, laba ditahan terhadap total aset, laba sebelum 
bunga dan pajak terhadap total aset, dan nilai buku ekuitas terhadap nilai buku utang (Rudianto,2013:219).

\section{Rumusan Masalah}

Berdasarkan latar belakang di atas, maka rumusan masalah dalam penelitian ini adalah "Bagaimana Penerapan Altman Z-Score Dalam Memprediksi Kebangkrutan Pada PT Bank Danamon Indonesia Tbk Periode 2018 s.d. 2020?".

\section{Tujuan Penelitian}

Tujuan penelitian ini adalah untuk mengetahui prediksi kebangkrutan pada PT Bank Danamon Indonesia Tbk periode 2018 s.d. 2020 menggunakan Altman ZScore.

\section{TINJAUAN PUSTAKA}

\section{Kebangkrutan}

Menurut Kamus Besar Bahasa Indonesia (KBBI), bangkrut berarti menderita kerugian besar hingga jatuh (tentang perusahaan, toko, dan sebagainya), atau gulung tikar. Kebangkrutan adalah ketidakmampuan perusahaan untuk membayarkewajiban keuangannya pada saat jatuh tempo yang menyebabkankebangkrutan atau kesulitan likuiditas yang mungkin sebagai awal kebangkrutan (Rudianto, 2013:251).

\section{Bank}

Menurut Kamus Besar Bahasa Indonesia (KBBI) bank adalah badan usaha di bidang keuangan yang menarik dan mengeluarkan uang dalam masyarakat, terutama memberikan kredit dan jasa dalam lalu lintas pembayaran dan peredaran uang.

\section{Rumus Altman Z-Score Ketiga (Modifikasi)}

Menurut Rudianto (2013:257) Altman melakukan penelitian lagi mengenai potensi kebangkrutan perusahaan-perusahaan selain perusahaan manufaktur, baik yang go public maupun yang tidak. Rumus Z-Score terakhir merupakan rumus yang sangat fleksibel karena bisa digunakan untuk berbagai jenis bidang usaha perusahaan, baik yang go public maupun yang tidak, dan cocok digunakan di negara berkembang seperti Indonesia. Hasil penelitian tersebut menghasilkan rumus Z-Score ketiga untuk berbagai jenis penelitian, sebagai berikut:

$\mathrm{Z}=6,56 \mathrm{X} 1+3,26 \mathrm{X} 2+6,72 \mathrm{X} 3+1.054 \mathrm{X} 4$

Hasil perhitungan dengan menggunakan rumus Z-Score modifikasi akan menghasilkan skor yang berbeda antara satu perusahaan dengan perusahaan lainnya. Skor tersebut harus dibandingkan dengan standar penilaian berikut ini untuk menilai keberlangsungan hidup perusahaan tersebut:

$\mathrm{Z}>2,6=$ Zona Aman

$1,1<\mathrm{Z}<2,6=\mathrm{Zona}$ Abu-Abu

$\mathrm{Z}<1,1=$ Zona Berbahaya

Dengan keterangan sebagai berikut:

$\mathrm{Z}=$ Bankruptcy Index

$\mathrm{X} 1$ = Modal Kerja terhadap Total Aset

X2 = Laba Ditahan terhadap Total Aset

X3 = Laba Sebelum Bunga dan Pajak terhadap Total Aset

X4 = Nilai Buku Ekuitas terhadap Nilai Buku Utang

Adapun definisi dan rasio yang digunakan dalam rumus di atas adalah sebagai berikut:

a. Variabel X1 (Modal Kerja Terhadap Total Aset) Menurut Rudianto (2013:255), Mengukur likuiditas dengan membandingkan aset likuid bersih dengan total aset. Aset likuid bersih atau modal kerja didefinisikan sebagai asetl ancar dikurangi total kewajiban lancar (aset lancar-utang lancar). Umumnya, bila perusahaan mengalami kesulitan keuangan, modal kerja akan menurun lebih cepat ketimbang total aset sehingga menyebabkan rasio ini turun. 
b. Variabel X2 (Laba Ditahan Terhadap Total Aset) Rasio ini menunjukkan rasio profitabilitas yang mendeteksi kemampuan perusahaan dalam menghasilkan keuntungan. Rasio ini mengukur besarnya kemampuan suatu perusahaan dalam memperoleh keuntungan, ditinjau dari kemampuan perusahaan bersangkutan dalam memperoleh laba dibandingkan kecepatan perputaran operating assets sebagai ukuran efisiensi usaha atau dengan kata lain, rasio ini mengukur akumulasi laba selama perusahaan beroperasi.

c. Variabel X3 (Laba Sebelum Bunga dan Pajak Terhadap Total Aset) Rasio ini mengukur profitabilitas, yaitu tingkat pengembalian atas aset, yang dihitung dengan membagi laba sebelum bunga dan pajak (Earning Before Interest and Tax) tahunan perusahaan dengan total aset pada neraca akhir tahun. Rasio ini menjelaskan pentingnya pencapaian laba perusahaan terutama dalam rangka memenuhi kewajiban bunga para investor.

d. Rasio ini merupakan kebalikan dari utang terhadap modal sendiri (debt to equity ratio). Nilai modal sendiri yang dimaksud adalah nilai pasar modal sendiri, yaitu jumlah saham perusahaan yang dikalikan dengan pasar saham per lembarnya (jumlah lembar saham x harga pasar saham per lembar). Umumnya, perusahaan-perusahaan yang gagal akan mengakumulasikan lebih banyak utang dibandingkan modal sendiri.

\section{METODE}

\section{Populasi dan Sampel}

Populasi adalah wilayah generalisasi yang terdiri atas obyek/subyek yang mempunyai kualitas dan karakteristik tertentu yang ditetapkan oleh peneliti untuk dipelajari dan kemudian ditarik kesimpulannya ( Sugiyono 2018:130). Dalam penelitian ini populasi yang digunakan adalah Laporan Keuangan PT Bank Danamon IndonesiaTbk yang diperoleh dari situs www.danamon.co.id.

Dalam penelitian ini teknik sampel yang digunakan adalah Purposive Sampling. Purposive sampling adalah teknik penentuan sampel dengan pertimbangan atau kriteria-kriteria tertentu (Sujawerni, 2015:88). Adapun dalam penelitian ini kriteria yang ditentukan oleh penulis adalah laporan posisi keuangan dengan pos-pos laporan keuangan yaitu aset lancar, utang lancar, laba ditahan, nilai buku ekuitas, nilai buku utang dan laporan laba rugi dengan pos-pos laporan keuangan yaitu laba sebelum bunga dan pajak pada PT Bank Danamon Indonesia Tbk periode 2018 s.d. 2020.

\section{Jenis Data}

Jenis data yang digunakan dalam penelitian ini adalah Data Sekunder Menurut Sugiyono (2017:137) menjelaskan data sekunder adalah sebagai berikut:"Sumber data yang tidak langsung memberikan data kepada pengumpul data. Data sekunder ini merupakan data yangsifatnya mendukung keperluan data primer seperti buku-buku, literatur dan bacaan yang berkaitan dan menunjang penelitian ini". Data sekunder yang digunakan dalam penelitian ini adalah Laporan Keuangan PT Bank Danamon Indonesia Tbk periode 2018 s.d. 2020 yang diakses melalui situs www.danamon.co.id.

\section{Teknik Analisis Data}

Adapun rumus Altman Z-Score modifikasi adalah sebagai berikut:

$\mathrm{Z}=6,56 \mathrm{X} 1+3,26 \mathrm{X} 2+6,72 \mathrm{X} 3+1,05 \mathrm{X} 4$

Adapun nilai cut off yang digunakan adalah:

$\mathrm{Z}>2,6=$ Zona Aman

$1,1<\mathrm{Z}<2,6=\mathrm{Zona}$ Abu-Abu

$\mathrm{Z}<1,1=$ Zona Berbahaya

Keterangan :

$\mathrm{Z}=$ Bankruptcy Indeks 
$\mathrm{X} 1=$ Modal kerja $:$ Total Aset

$\mathrm{X} 2$ = Laba ditahan : Total Aset

X3 = Laba Sebelum Bunga dan Pajak: Total Aset

X4 = Nilai Buku Ekuitas : Nilai Buku Utang

\section{HASIL DAN PEMBAHASAN}

Berdasarkan data laporan keuangan yang diperoleh dari (Laporan Publisitas Tahunan Bank Danamon 2018-2020 n.d.) maka terdapat pos - pos laporan keuangan yang akan digunakan dalam menghitung Altman Z- Score modifikasi.

a. Rasio Net Working Capital to Total Assetss (X1)

Tabel. Perhitungan Net Working Capital to Total Assetss PT Bank Danamon Indonesia Tbk Periode 2018 - 2020 ( Dalam Jutaan Rupiah )

\begin{tabular}{|l|l|l|l|}
\hline Tahun & Aset Lancar & Utang Lancar & Modal Kerja \\
\hline 2018 & 183.271 .660 & 133.037 .061 & 50.234 .599 \\
\hline 2019 & 189.980 .557 & 133.226 .243 & 56.754 .314 \\
\hline 2020 & 196.835 .225 & 146.651 .266 & 50.183 .959 \\
\hline
\end{tabular}

Tabel. Perhitungan X1 Net Working Capital to Total Assetss PT Bank Danamon Indonesia Tbk Periode 2018- 2020 ( Dalam Jutaan Rupiah )

\begin{tabular}{|l|l|l|l|}
\hline Tahun & Modal Kerja & Total Aset & Net Working Capital to Total Assetss \\
\hline 2018 & 50.234 .599 & 186.762 .189 & 0,2689 \\
\hline 2019 & 56.754 .314 & 193.533 .970 & 0,2932 \\
\hline 2020 & 50.183 .959 & 200.890 .068 & 0,2498 \\
\hline
\end{tabular}

Penjelasan :

1. Pada tahun 2018, rasio X1 sebesar 0,2689 yang artinya setiap Rp. 1,00 total Aset mampu dijamin oleh modal kerja bersih sebesar 0,2689. Nilai rasio tersebut merupakan hasil pembagian antara modal kerja bersih sebesar Rp. 50.234.599 dengan total aset sebesar Rp. 186.762.189.

2. Pada tahun 2019, rasio X1 sebesar 0,2932 yang artinya setiap Rp. 1,00 total Aset mampu dijamin oleh modal kerja bersih sebesar 0,2932. Nilai rasio tersebut merupakan hasil pembagian antara modal kerja bersih sebesar Rp. 56.754.314 dengan total aset sebesar Rp. 193.533.970

3. Pada tahun 2020, rasio X1 sebesar 0,2498 yang artinya setiap Rp. 1,00 total Aset mampu dijamin oleh modal kerja bersih sebesar 0,2498. Nilai rasio tersebut merupakan hasil pembagian antara modal kerja bersih sebesar Rp. 50.183.959 dengan total aset sebesar Rp. 200.890.068.

b. Rasio Retained Earnings to Total Assets (X2)

Tabel. Perhitungan X2 Retained Earnings to Total Assets PT Bank Danamon Indonesia Tbk Periode 2018- 2020 ( Dalam Jutaan Rupiah )

\begin{tabular}{|l|l|l|l|}
\hline Tahun & Laba Ditahan & Total Aset & Retained Earnings to Total Assets \\
\hline 2018 & 390.062 & 186.762 .189 & 0,0020 \\
\hline 2019 & 429.284 & 193.533 .970 & 0,0022 \\
\hline 2020 & 470.018 & 200.890 .068 & 0,0023 \\
\hline
\end{tabular}

Penjelasan :

1. Pada tahun 2018, rasio X2 menunjukkan 0,0020 yang artinya setiap Rp. 1,00 total aset yang dimiliki oleh Bank Danamon Indonesia Tbk mampu menghasilkan laba ditahan sebesar 0,0020 . 
2. Pada tahun 2019, rasio X2menunjukkan 0,0022 yang artinya setiap Rp. 1,00 total aset yang dimiliki oleh Bank Danamon Indonesia Tbk mampu menghasilkan laba ditahan sebesar 0,0022 .

3. Pada tahun 2018, rasio X3 menunjukkan 0,0023 yang artinya setiap Rp. 1,00 total aset yang dimiliki oleh Bank Danamon Indonesia Tbk mampu menghasilkan laba ditahan sebesar 0,0023 .

c. Rasio Earnings Before Interes and Taxes to Total Assets ( X3 )

Tabel. Perhitungan X3 Earnings Before Interes and Taxes to Total Assets PT Bank Danamon Indonesia Tbk Periode 2018- 2020 ( Dalam Jutaan Rupiah )

\begin{tabular}{|l|l|l|l|}
\hline Tahun & EBIT & Total Aset & Earnings Before Interes and Taxes to Total Assets \\
\hline 2018 & 4.925 .686 & 186.762 .189 & 0,0263 \\
\hline 2019 & 5.487 .790 & 193.533 .970 & 0,0283 \\
\hline 2020 & 2.067 .076 & 200.890 .068 & 0,0102 \\
\hline
\end{tabular}

Penjelasan :

1. Pada tahun 2018 , rasio laba sebelum pajak terhadap total Aset menunjukkan rasio X3 sebesar 0,0263 yang artinya setiap Rp 1,00 total Aset dapat menghasilkan laba sebelum pajak sebesar 0,0263 .

2. Pada tahun 2019 , rasio laba sebelum pajak terhadap total Aset menunjukkan rasio X3 sebesar 0,0283 yang artinya setiap Rp 1,00 total Aset dapat menghasilkan laba sebelum pajak sebesar 0,0283 .

3. Pada tahun 2018 , rasio laba sebelum pajak terhadap total Aset menunjukkan rasio X3 sebesar 0,0102 yang artinya setiap Rp 1,00 total Aset dapat menghasilkan laba sebelum pajak sebesar 0,0102 .

d. Book Value of Equity to Book Value of Debt (X4)

Tabel. Perhitungan X4 Book Value of Equity to Book Value of Debt PT Bank Danamon Indonesia Tbk Periode 2018- 2020 ( Dalam Jutaan Rupiah )

\begin{tabular}{|l|l|l|l|}
\hline Tahun & $\begin{array}{l}\text { Nilai Buku } \\
\text { Ekuitas }\end{array}$ & $\begin{array}{l}\text { Nilai Buku } \\
\text { Utang }\end{array}$ & $\begin{array}{l}\text { Book Value of Equity to Book Value of } \\
\text { Debt }\end{array}$ \\
\hline 2018 & 41.939 .821 & 144.822 .368 & 0,2895 \\
\hline 2019 & 45.417 .027 & 148.116 .943 & 0,3066 \\
\hline 2020 & 43.575 .499 & 157.314 .569 & 0,2769 \\
\hline
\end{tabular}

Penjelasan:

1. Pada 2018, rasio total ekuitas atau modal terhadap total utang atau liabilitas menunjukkan rasio X4 sebesar 0,2895 yang artinya setiap Rp 1,00 total utang mampu dijamin oleh total ekuitas sebesar 0,2895 .

2. Pada 2018, rasio total ekuitas atau modal terhadap total utang atau liabilitas menunjukkan rasio X4 sebesar 0,3066 yang artinya setiap Rp 1,00 total utang mampu dijamin oleh total ekuitas sebesar 0,3066 .

3. Pada 2018, rasio total ekuitas atau modal terhadap total utang atau liabilitas menunjukkan rasio X4 sebesar 0,2769 yang artinya setiap Rp 1,00 total utang mampu dijamin oleh total ekuitas sebesar 0,2769 .

Perhitungan Z- Score untuk tahun 2018 :

$\mathrm{Z}=6,56 \mathrm{X} 1+3,26 \mathrm{X} 2+6,72 \mathrm{X} 3+1,05 \mathrm{X} 4$

$Z=6,56(0,2689)+3,26(0,0020)+6,72(0,0263)+1,05(0,2895)$

$\mathrm{Z}=1,7639+0,0065+0,1767+0,3039$

$\mathrm{Z}=2,251$ 


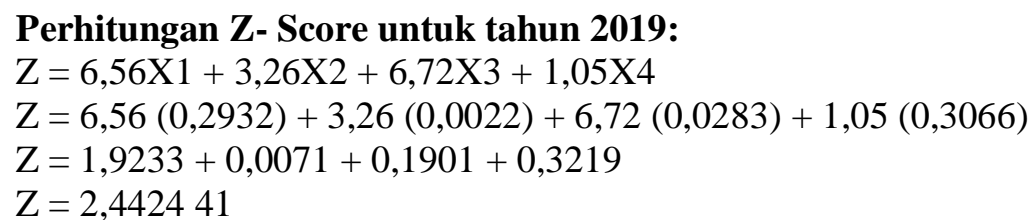

Perhitungan Z- Score untuk tahun 2020:

$\mathrm{Z}=6,56 \mathrm{X} 1+3,26 \mathrm{X} 2+6,72 \mathrm{X} 3+1,05 \mathrm{X} 4$

$Z=6,56(0,2498)+3,26(0,0023)+6,72(0,0102)+1,05(0,2769)$

$Z=1,6386+0,0074+0,0685+0,2907$

$\mathrm{Z}=2,0052$

Tabel. Hasil Altman Z- Score PT Bank Danamon Indonesia Tbk Periode Tahun 2018 2020

\begin{tabular}{|l|l|l|l|l|l|l|}
\hline Tahun & X1 & X2 & X3 & X4 & Z- Score & Hasil Analisis \\
\hline 2018 & 0,2689 & 0,0020 & 0,0263 & 0,2895 & 2,251 & Zona abu - abu \\
\hline 2019 & 0,2932 & 0,0022 & 0,0283 & 0,3066 & 2,4424 & Zona abu - abu \\
\hline 2020 & 0,2498 & 0,0023 & 0,0102 & 0,27699 & 2,0052 & Zona abu - abu \\
\hline $\begin{array}{l}\text { Rata } \\
2,2328\end{array}$ & - & rata & Zona abu - abu \\
\hline
\end{tabular}

Berdasarkan tabel diatas, hasil perhitungan Altman Z- Score pada Bank Danamon Tbk periode 2018 - 2020 menunjukkan bahwa Bank Danamon berada di zona abu - abu. Hal ini dibuktikan dengan nilai cut off $1,1<\mathrm{Z}$ tepat. Hasil Altman Z- Score tahun 2018 diperoleh nilai sebesar 2,251. Nilai tersebut jika diteliti disebabkan karena nilai rasio X1 sebesar 0,2689 yang artinya setiap Rp 1,00 total Aset mampu dijamin oleh modal kerja bersih sebesar 0,2689. Nilai rasio tersebut merupakan hasil pembagian antara modal kerja bersih sebesar Rp 50.234.599 dengan total aset sebesar $\mathrm{Rp}$ 186.762.189.

Kemudian diperoleh rasio X2 Bank Danamon Indonesia Tbk mampu menghasilkan laba ditahan sebesar 0,0020. Rasio X3 dapat menghasilkan laba sebelum pajak sebesar 0,0263. Total ekuitas atau modal terhadap total utang atau liabilitas menunjukkan rasio X4 sebesar 0,2769 yang artinya setiap Rp 1,00 total utang mampu dijamin oleh total ekuitassebesar 0,2769 . Tahun 2019 Hasil Altman Z- Score diperoleh nilai sebesar 2,4424 yang merupakan nilai tertinggi dari 3 tahun periode yang diteliti. Nilai tersebut disebabkan oleh kenaikan modal kerja bersih sebesar $0,0903 \%$, serta kenaikan nilai buku ekuitas terhadap nilai utang sebesar 0,0049\% dari tahun 2018 Tahun 2020 menunjukkan nilai Altman Z- Score yang paling kecil sebesar 2,0052. Perusahaan dalam kondisi rawan ( grey area ).

Bank Danamon mengalami masalah keuangan yang harus ditangani dengan cara yang tepat dengan mengalami penurunan nilai variabel X1 modal kerja bersih ( net working asetss ), variabel X3 Earning before interest and taxes, variabel X4 Book value of equity sebesar 0,0434 $\%, 0,0181 \%, 0,4372 \%$. Hasil analisis prediksi kebangkrutan pada PT Bank Danamon Tbk periode 2018 s.d. 2020 mengalami fluktuasi yang berbeda, pada periode 2018 s.d. 2019 mengalami kenaikan. Namun pada periode 2020 mengalami penurunan.

\section{SIMPULAN}

Berdasarkan hasil pengolahan data dan pembahasan, maka dapat disimpulkan bahwa penerapan Altman Z-Score pada PT Bank Danamon Indonesia Tbk periode 2018 s.d. 2020 berada dalam zona abu - abu (grey area ) karena dari hasil analisis berada dirata - rata 2,2328 nilai cut off yang ditentukan $1,1<\mathrm{Z}$

\section{SARAN}

Dari simpulan di atas, diharapkan pihak manajemen PT Bank Danamon Indonesia Tbk dapat memerhatikan kondisi keuangan perusahaan dan besar kecilnya rasio-rasio keuangan yang 
digunakan dalam memprediksi kebangkrutan untuk menghindari gejala terjadinya financial distress, dengan mengetahui prediksi kebangkrutan membantu menghindarkan perusahaan dari terjadinya kebangkrutan dan bisa melakukan perbaikan.

\section{DAFTAR PUSTAKA}

Hanafi, Mamduh M dan Abdul Hakim. 2014. Analisis Laporan Keuangan. Ketujuh. Yogyakarta: UPP AMP YKPN.

Hery. 2017. Kajian Riset Akuntansi: Mengulas Berbagai Hasil Penelitian Terkini Dalam Bidang Akuntansi Dan Keuangan. Jakarta: PT Grasindo.

I gusti dkk. 2014. Akuntansi Perbankan.Jakarta.Erlangga.

Ismail. 2010. Manajemen Perbankan Dari Teori Menuju Aplikasi. Jakarta: Prenadamedia Group.

Kasmir. 2016. Dasar Dasar Perbankan. Jakarta: Rajawali Pers. ——. 2018. Analisis Laporan Keuangan. Jakarta: Rajawali Pers.

Munawir. 2014. Analisis Laporan Keuangan. Yogyakarta: Liberty. Rudianto. 2013. Akuntansi Manajemen. Jakarta: Penerbit Erlangga.

Sugiyono. 2017. Metode Penelitian Kuantitatif,Kualitatif, Dan RD. Bandung: Alfabeta.

Sujaweni, V, W. 2015. Metodologi Penelitian Bisnis \& Ekonomi. Yogyakarta: Pustakabarupress.

Bestary. 2019. "Penerapan Altman Z- Score Dalam Memprediksi Kebangkrutan Pada Bank Mandiri (PERSERO) Tbk." file:///C:/Users/acer/Downloads/189-BK-TA-19.pdf.

Febriola, Priskila, and Lumban Tobing. 2019. "Prediksi Potensi Kebangkrutan Pada Pt Bank Sumut Dengan Metode Altman Z-Score."

Rahmawan, Aditya Rofi. 2015. "Analisis Potensi Kebangkrutan Pada PT. Bank Negara Indonesia Tbk Dengan Menggunakan Metode Altman Z- Score." Indonesia, Republik. 1998. "Undang-Undang No. 10 Tahun 1998 Tentang Perbankan." Lembaran Negara Republik Indonesia: 182. http://www.bphn.go.id/data/documents/98uu010.pdf. 